\title{
Adaptability of Primary and Middle Schools to Post-Pandemic Reuse - A Discussion in the Context of Flexibility
}

\author{
Orkan Zeynel Guzelci \\ University of Porto, Faculty of Architecture, DFL, Porto, Portugal (Corresponding Author) \\ Sema Alacam \\ İstanbul Technical University, Faculty of Architecture, İstanbul, Turkey \\ Serkan Kocabay \\ DB Architects, İstanbul, Turkey \\ Elif Isik Akkuyu ๑ \\ Ryerson University, Department of Geography, Toronto, Canada
}

\begin{abstract}
Received: August 3rd 2020, Revised: August 28th 2020, Accepted: September 3rd 2020
Refer: Guzelci, O. Z., Alacam, S., Kocabay, S., Akkuyu, E. I., (2020), Adaptability of Primary and Middle Schools to Post-Pandemic Reuse - A Discussion in the Context of Flexibility, Journal of Design Studio, V.2, N.2, pp 5-22,

O. Z. Guzelci ORCID: 0000-0002-5771-4069, S. Alacam ORCID: 0000-0002-5979-3282, S. Kocabay ORCID: 0000-0002-0803-3224, E. I. Akkuyu ORCID: 0000-0002-0969-1843
\end{abstract}

\begin{abstract}
This study discusses how the existing primary and middle school buildings can be adapted to the new needs emerging in the Covid-19 process. The three levels of adaptation are defined as follows: Building envelopeoutdoor space relationship, plan layout-function relationship, and furniture relocation. In the scope of this study, five selected school plans were evaluated in the context of flexibility in the plan layout-function relationship. In this study, the concept of "adaptation" is considered as a design approach at the early design phase and/or intervention to respond to a new need in the life cycle of the building.
\end{abstract}

Keywords: Education buildings, Primary Schools, Adaptability, Covid-19, Post-Pandemic

\section{Introduction}

The World Health Organization (WHO) (2010) defines "pandemic" as "worldwide spread of a new disease". The origins of "pandemic" can be traced back to Ancient Greek, where the root words "pan" meaning "everyone" and "demos" meaning "people" are combined to describe the phenomena (Online Etymology Dictionary, 2020). In 2020, the term pandemic has become a part of everyday vocabulary, all over the world. Following the WHO's official pandemic declaration due to a highly contagious virus, Covid-19, on 11th March 2020 (World Health Organization, 2020), the global social, cultural, and economical relations have been radically affected by the outbreak. In addition, the duration of the pandemic-based regulation remains uncertain, as well as the methodologies of overcoming strategies. As of July 30, 2020, 17.031.281 cases and 667.060 deaths have been officially reported in 213 countries under Covid-19, and this table is getting more and more severe (Worldometer, 2020). The measures taken against Covid-19 are updated dynamically with the experiences gained worldwide. Accordingly, there emerged frequent and rapid responses by governments regulating the transportation of people and 


\section{Journal of \\ Design Studio}

v:2 n:2 December 2020

goods on a large scale (i.e. buildings, cities, or nations). Among several measures against the spread of Covid-19, "social distancing" became more apparent regarding the spaces and their affordances.

Due to the uncertain nature of Covid-19 spread, it is difficult to anticipate any emerging needs and their potential effects on architectural practice. On the other hand, how existing spaces can respond to changing functions / routines / regulations becomes a topic of discussion. Since the current pandemic has specific characteristics different from the historically observed outbreaks, there are no direct precursors to the applications and architectural strategies to be developed. Meanwhile, in Turkey, regulations, and planning in regards to spaces where individuals could spend time and socialize in groups are periodically updated.

Education is one of the areas most directly affected by this uncertainty. New measures are defined according to the speed of the progression of Covid-19. However, studies concerned with the adaptation of educational buildings to the "new normal" and studies concerned with future projections of social spaces are especially limited. In addition to many other contradictions and tensions, the challenges in the adaptation of educational buildings to changing needs after the pandemic are deepening, especially in dense cities, like İstanbul. Keeping these ambiguities in mind, this study examines how existing primary and middle school buildings can be adapted to the post-pandemic process. To discuss the adaptation of existing buildings to the new needs emerging in the post-pandemic process, the following three levels are proposed:

- Building envelope-outdoor space relationship: New additions to existing buildings, changes to the building envelope;

- Plan layout-function relationship: Creating new spaces through transforming the separator elements in the interior and changes to the existing functions;

- Furniture relocation: Changes made through the displacement of moveable fittings without interfering with the structural elements.

The reasons for proposing three levels of adaptation can be listed as follows: being able to evaluate the discussions on flexibility and adaptation at different levels and scales in the literature (Abbasi, 2016; Tapk1 \& Canbay Türky1lmaz, 2012; Woodman, 2016) and to define the scope more clearly in a way that it reveals the original contribution of the study different from existing studies. The authors argue that revisiting the concept of flexibility by architects might provide insights to frame the problem of adaptation to the Post-Pandemic period. Within the scope of this study, the adaptation opportunities of primary and middle schools to the emerging needs in the Covid-19 era are discussed in the context of flexibility in the plan layout-function relationship.

\section{Existing School Building, New Needs and Problems}

The official data of the Ministry of Education of Turkey in 2019 (T.C. Milli Eğitim Bakanlığ 2019) illustrates that at the primary school level, there are 22.931 public and 1808 private schools, with a count of 5.005.214 public and 262.164 private school students. Primary school students are educated by 268.065 public and 32.667 private school teachers. At the middle school level, there are 16.874 public and 2060 private schools with a count of 5.099.275 public and 338.046 private school students. Middle school students are educated by 312.761 public and 41.437 private school teachers. Therefore, due to the pandemic outbreak, the new needs and faced problems in existing school buildings concerns 10.704 .699 students, 654.930 teachers, and their families in total throughout the country.

Over time, while the number of students has increased rapidly at primary and middle school levels, this increase has not been proportionated to the number of teachers and school buildings available. When it comes to the adaptation of school buildings to changing external conditions, it is observed that design solutions with the goal of only increasing the capacity of buildings are at the forefront and the issues related to the quality of buildings remain in the 


\section{Journal of \\ Design Studio}

v:2 n:2 December 2020

background. Due to economic and temporal limitations and the expectation of standardization (Köse \& Barkul, 2012) "typical projects" are preferred by the Ministry of Education of Turkey (MEB). MEB's justification for the selection of "typical projects" are construction (easy to operate) and post-occupancy (easy to maintain) based. Typical projects are defined as designs that are independent from environmental factors and the surrounding built environment (Tapk1 \& Canbay Türkyılmaz, 2018). Although the preference of "typical projects" appears to be more economic and efficient in the short term, the adaptation of educational buildings planned as typical projects to the new requirements of Covid-19 becomes arguable, considering the long-term costs.

With the measures taken against Covid-19, the Ministry of Education of Turkey has suspended in-person education throughout the year, as of March 16, 2020 (T.C. Milli Eğitim Bakanlığ March 13, 2020). As of March 23, 2020 (T.C. Milli Eğitim Bakanlığı, March 17, 2020), distance-education has commenced in all levels of education, partially and/or for an indefinite time. On the other hand, there is much uncertainty regarding when educational buildings will be reopened for in-person education.

In this context, some problems and needs that may be encountered are listed below:

- Can existing educational buildings enable social distancing measures?

- What kind of new problems may be encountered if educational buildings are used with a 50 percent occupancy?

- Can existing school buildings be used with natural ventilation systems without the need for mechanical ventilation infrastructures?

- Is it possible to develop new principles and guidelines on the re-functioning and newfound use of common spaces such as washrooms, change rooms, sports halls, and dining halls?

- How will the transformation of routines and social behaviour (with respect to social distancing and changes to the previously open-purchased, unwrapped cafeteria goods) reflect on the design and use of common spaces such as cafeteria and stationery shops?

In the context of adaptation of educational buildings to new needs arising due to the pandemic, the parameters that are more difficult to change can be listed: number of teachers, number of students, count of available school buildings, and the envelope of the buildings. The envelopes of the buildings are highly difficult to change as they are dependent on spatial factors such as land-size, borders of the courtyards, and high densities associated with the located neighbourhoods. Therefore, the growth possibilities of the buildings in dense urban environments are limited.

In projections where there are no expected major changes to the number of teachers and students, the institutions that provide full-time education seek methods to return to the dual education system, which consists of morningafternoon sessions to decrease the capacity of education spaces to 50 percent. However, a factor that constrains dual education planning are limitations in the number of teachers within the educational system. Despite institutions aiming to continue with the dual education approach (TRT Haber, 2018), due to social distance requirements in buildings, there is a need for transforming existing spaces used for different functions (i.e. dining hall, sports hall, libraries, etc.) in educational buildings to classrooms.

Considering the affordances of the interior space in the educational buildings, the number of students that can use a classroom simultaneously can be assumed as one of the major problems. However, apart from the closed spaces like classrooms, circulation in the buildings and new "intermediate spaces" that can meet the disinfection needs of people and objects between outdoor and indoor spaces become problematic. Additionally, not only the movement of people but also how the air will flow throughout the building or how the circulation will be controlled still remain unsolved. 


\section{Journal of \\ Design Studio}

v:2 n:2 December 2020

\section{Adaptation Approaches in Educational Buildings and Flexibility as An Affordance}

Although there are numerous studies on the adaptation of educational buildings to the new education systems, trends and requirements (Abbasi, 2016; Dovey \& Fisher, 2014; Karabey, 2004; Kizıltan, 1967; Tapk1 \& Canbay Türky1lmaz; Woodman, 2016), studies are very limited on the topic of adaptation of educational buildings to pandemic scenarios, such as Covid19. The concept of adaptation has been mostly discussed in relation to flexibility (Dovey \& Fisher, 2014; Karabey, 2004; Yürekli, 1983), changeability (Kiz1ltan, 1967) and ability to grow (Kiziltan, 1967; Yürekli, 1983). In the scope of this study, the concept of "adaptation" is considered as a need-based design approach during the early phases of design and/or an alternative solution to meet new requirements faced during the post-occupancy phases of the buildings (functional, performative, structural). Different combinations and sequences of adaptation approaches provide a well-balanced state of flexibility in buildings. On the other hand, it is difficult to provide a definition for flexibility where the requirements change continuously. In this sense, flexibility indicates a potential and an affordance that has not yet actualized itself. In its broad form, adaptation is the convergence of a given environment / situation / organism in its level of resilience to meet its needs based on the setting, where flexibility refers to an unactualized potential for an unknown future.

There is not a consensus on the meanings of the concepts of flexibility, changeability, and growth and the contexts in which they are used. Kiziltan defines flexibility in the context of primary school buildings as a combination of the following features: ability to expand, change, and be modified (Kizıltan, 1967; Yürekli, 1983). Kızıltan (1967) also defines "ability to expand" as merging a classroom(s) to obtain bigger classrooms or meeting halls as well as adding new classrooms to the educational building or reducing the number of classrooms; "ability to change" is defined as not only to expand the area of the space with educational purposes but also the ability to re- organize these spaces to provide opportunities for new and changed activities. Lastly, "ability to be modified" refers to the ability to modify all separating partition walls, not including structural systems and building envelopes (Yürekli, 1983).

Woodman (2016) discusses the concept of flexibility in the context of educational buildings; the following are discussed on the axis of time, space, use, and movements. Time flexibility according to Woodman (2016) refers to the "ability of a structure to change over an extended period of time to satisfy significant changes in need", while space flexibility is related to the "transformational type of change" in the spatial arrangements. Woodman (2016) considers "use flexibility" as the affordances of the same place being open to different uses, while "movement" flexibility" indicates the movement of teachers and students.

In cases where identified needs of buildings change with time, and/or goals of the multiple adaptation approaches employed contradict amongst themselves, the following question remains: what kind of approaches can be adopted in the adaptation of such cases? For instance, an educational building that can be classified as flexible at a certain instance in time may be evaluated as not flexible at a different time instance, due to changes in needs with time, space and activities. Therefore, the benefit from the adaptation levels mentioned in the introduction section is necessary to discuss the different adaptation approaches and strategies presented in the existing literature (Table 1). In Table 1, underlined parts refer to the subjects discussed in the scope of this study. 
Table 1. Potential adaptation levels aiming to address flexibility in educational buildings.

\begin{tabular}{|c|c|c|c|}
\hline Level of Adaptation & $\begin{array}{l}\text { Tapkı \& Canbay } \\
\text { Türkyılmaz (2012) }\end{array}$ & Abbasi (2016) & Woodman (2016) \\
\hline $\begin{array}{l}\text { Building envelope- } \\
\text { outdoor space } \\
\text { relationship }\end{array}$ & $\begin{array}{l}\text {-Spatial, visual, auditory } \\
\text { and air temperature related } \\
\text { comfort conditions }\end{array}$ & $\begin{array}{l}\text {-Developing strategies to } \\
\text { reduce the scale of the } \\
\text { educational buildings }\end{array}$ & -Time flexibility \\
\hline $\begin{array}{l}\text { Plan layout-function } \\
\text { relationship }\end{array}$ & $\begin{array}{l}\text {-Ratio between physical } \\
\text { space and number of } \\
\text { students }\end{array}$ & $\begin{array}{l}\text {-Creating social spaces } \\
\text {-Promoting transparency } \\
\text { and visual relations } \\
\text {-Increasing flexibility }\end{array}$ & $\begin{array}{l}\text {-Space flexibility } \\
\text {-Movement } \\
\text { flexibility }\end{array}$ \\
\hline Furniture relocation & $\begin{array}{l}\text {-Appropriateness of } \\
\text { selected furnishings in } \\
\text { terms of ergonomics }\end{array}$ & $\begin{array}{l}\text {-Decision-making on } \\
\text { furniture design and } \\
\text { relocation }\end{array}$ & $\begin{array}{l}\text {-Use flexibility } \\
\text {-Movement } \\
\text { flexibility }\end{array}$ \\
\hline
\end{tabular}

In this study, adaptability of primary and middle school buildings to post-pandemic settings are discussed based on K1ziltan (1967)'s "ability to expand, change and be modified" framework through 5 existing sample projects. The design approaches discussed in this study are related to the "space flexibility" in Woodman (2016)'s classification. Moreover, this study focuses on the "decisions made in planning and layout" which Yürekli (1983) defines as an approach for flexibility and neglects the "decisions made in construction techniques and systems". In light of Covid-19, to meet social distance requirements, the potential of expandability of classrooms is examined while keeping the number of teachers, number of students, minimum number of classrooms, and building envelopes as constants. Figure 1 illustrates different plan layouts of educational buildings derived from various sources (de Graça, 2007; Dudek, 2007; Pereira et al., 2018). 
Classrooms located on a single side of the corridor

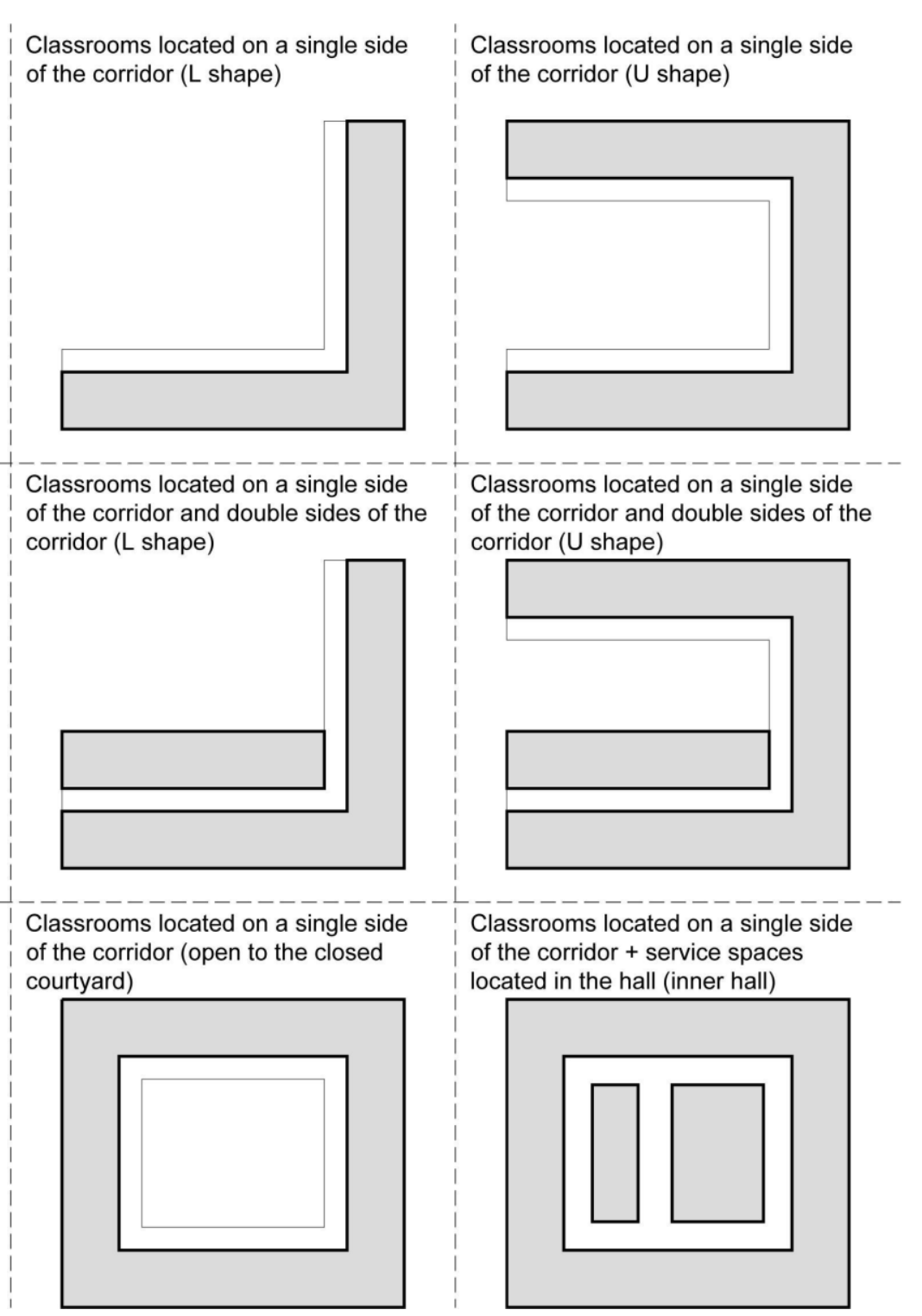

Figure 1. Various plan layouts of educational buildings (de Graça, 2007; Dudek, 2007; Pereira et al., 2018).

Although the classroom-circulation area relationships illustrated in Figure 1 provides advantages in many aspects during the construction process, these relationship types cannot respond to scenarios where the building envelope remains as constant; classrooms cannot be expanded into the remaining interior spaces due to spatial limitations within the buildings. To expand existing classrooms using the existing space in the interior of buildings, void spaces have to be defined. The plan schemes proposed by Dudek (2007) and shown in Figure 2 produce partial solutions to the need for expandability through interior spaces. 

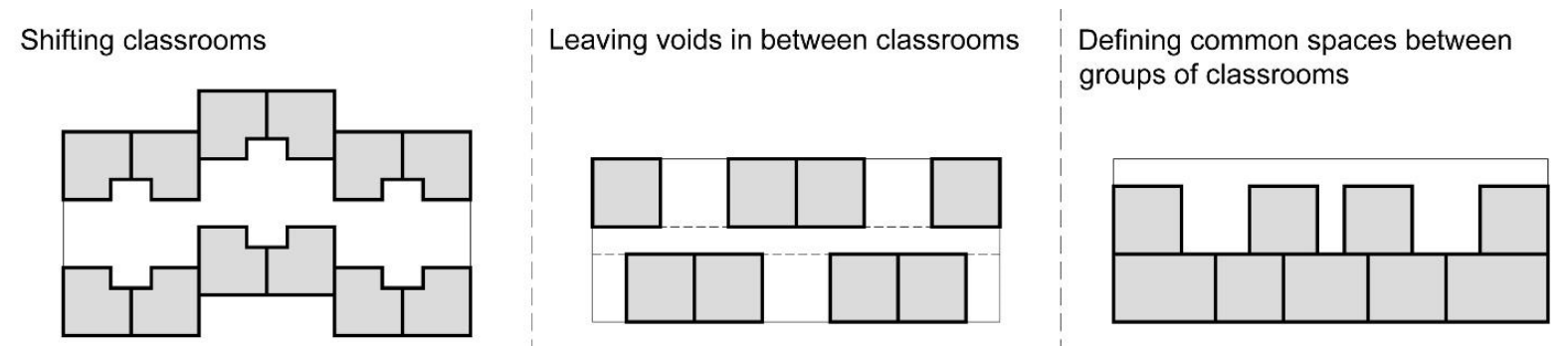

Figure 2. Design decisions for providing voids that can be applied to plan schemes illustrated in Figure 1 (Dudek, 2007).

\section{Flexibility of School Buildings in the Plan Layout Level}

In this section, the flexibility of primary and middle school buildings is examined through their plan schemas to check the appropriateness of educational buildings for the purpose of continuing educational activities in the postpandemic period. The first four projects examined in this study are schools, all of which are designed and built at different time periods and each with differing plan schemas. However, the fifth examined school project has not been constructed yet and characteristic features of this project are similar to the second project.

The first sample, Ataköy Primary School was designed by Muhteşem Giray in 1967, in relation to the population increase in the Ataköy neighbourhood. Ataköy Primary School is constructed on $8000 \mathrm{~m}^{2}$ lot, as a single floor. The building consists of 3 parts that are connected to each other with closed circulation areas (corridors). While two of these parts include classrooms, the third part includes a sports hall and offices. Each classroom has the same rectangular shape with dimensions of 7 to 8 meters and each classroom has its own private storage area. Based on his calculations, Muhteşem Giray (1967) claimed that Ataköy Primary School was not more costly than the constructed, preferred "typical projects". The plan typology of Ataköy Primary School can be identified as classrooms and service areas opening to a common central inner hall (Figure $3)$. 


\section{Journal of}

\section{Design Studio}

a

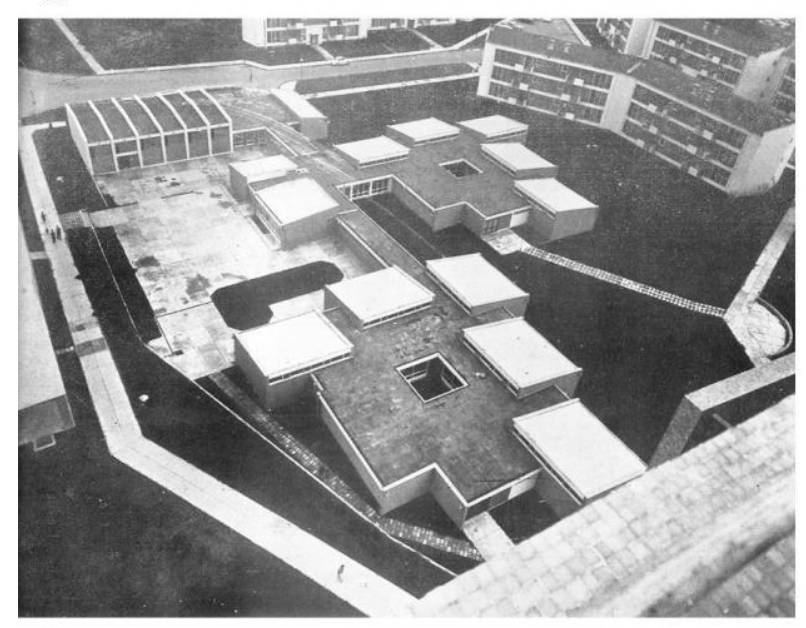

C b

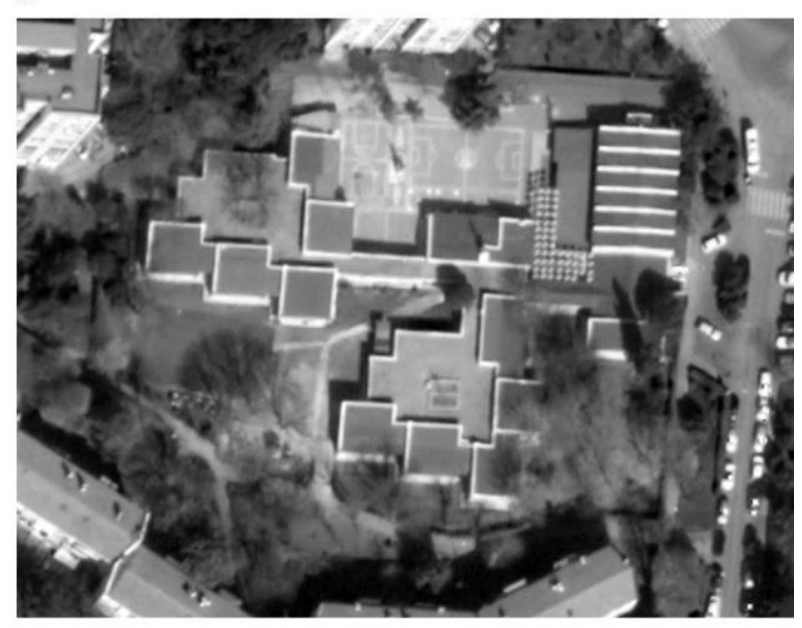

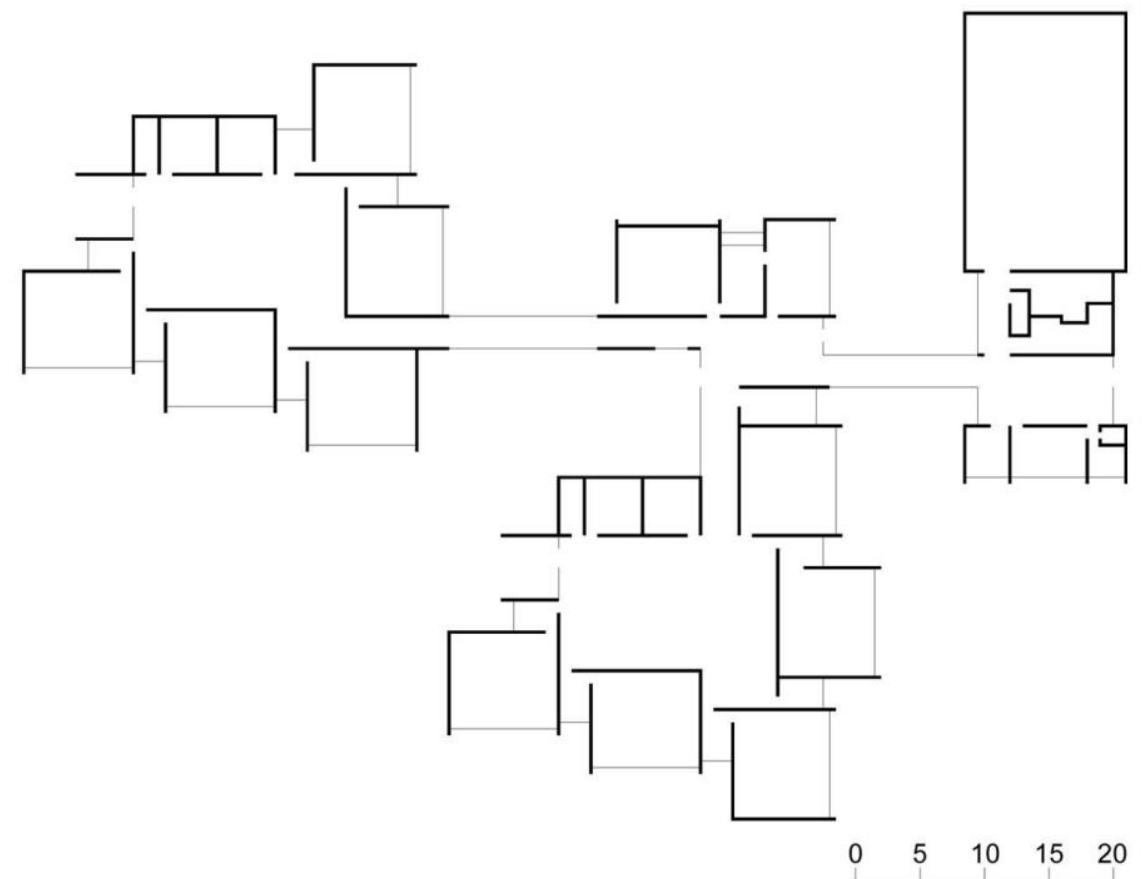

Figure 3. (a) "Primary School in Ataköy located in $2^{\text {nd }}$ Neighbourhood" designed by Giray (1967); (b) Aerial view of Ataköy Primary School, 2020; (c) Schematic plan drawing of the "Primary School in Ataköy located in $2^{\text {nd }}$ Neighbourhood" (Giray, 1967).

The middle school building including 21 classrooms was designed by Orhan Akyürek as a "typical project" for the Ministry of Public Works of the Republic of Turkey. This typical project was applied to sloped and flat lands to include 8,12 , and 16 classrooms, when necessary. It is known that the project by Orhan Akyürek is applied in neighbourhoods of İstanbul such as Şehremini, Baltalimanı, Çamlıca, Bakırköy, Esenler, and Kocasinan.
The plan schema of this design can be defined as classrooms located on the double-sides of the corridor (Akyürek, 1973). The building, which was found to be built as a middle school in 1970 in the Kocasinan district of İstanbul, is currently used as the Kocasinan Multi-Program Anatolian High School (Kocasinan MPAHS) (İstanbul Bahçelievler Kocasinan Çok Programlı Anadolu Lisesi, 2020) (Figure 4). 


\section{Journal of}

\section{Design Studio}

a

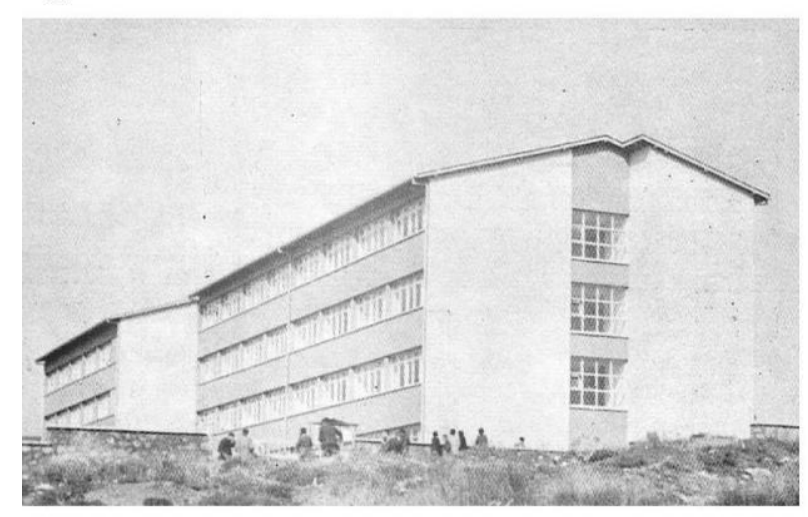

b

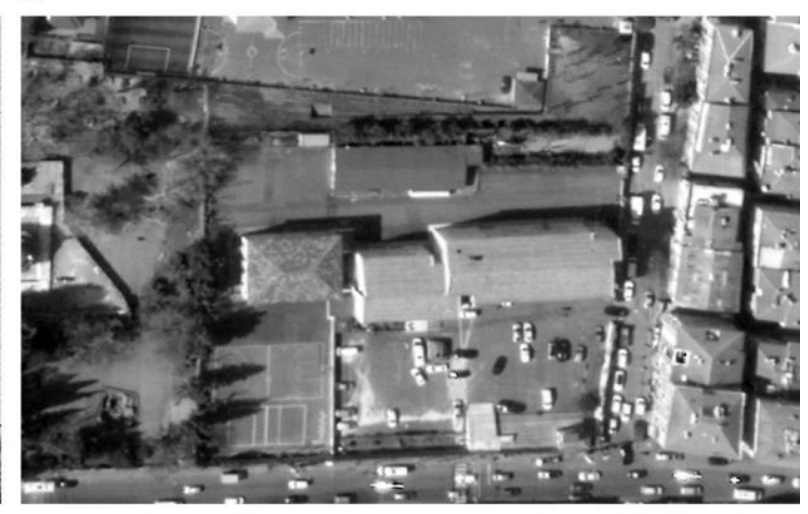

C

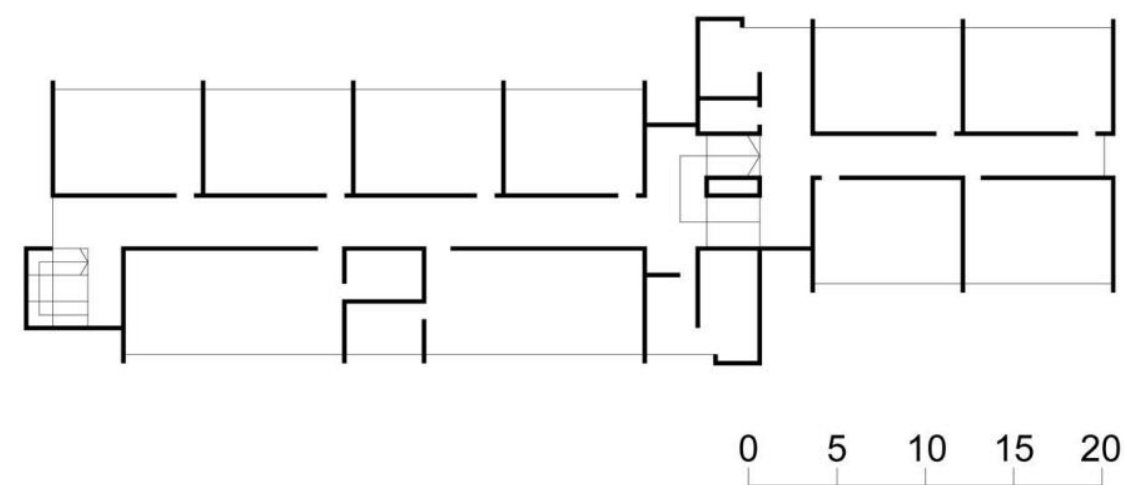

Figure 4. (a) "A Middle School Building" designed by Akyürek (1973); (b) Aerial view of Kocasinan MPAHS, 2020; (c) Schematic plan drawing of the "A Middle School Building” (Akyürek, 1973).

The main educational building of Fide Schools: İdealtepe Campus was designed by ddrlp Architecture and Design Services has 12 classrooms. Located in a highly urban setting, the campus consists of $1219 \mathrm{~m}^{2}$ of closed areas and $1291 \mathrm{~m}^{2}$ of open areas (Fide Okulları, 2020). While transforming a former textile factory into a school building, designers aimed to preserve open and green areas. To do so, designers added an external circulation element (staircase) to the building and developed a unique plan typology that includes two distinct inner halls (Arkiv, 2020) (Figure 5). 


\section{Journal of \\ Design Studio}

v:2 n:2 December 2020

a

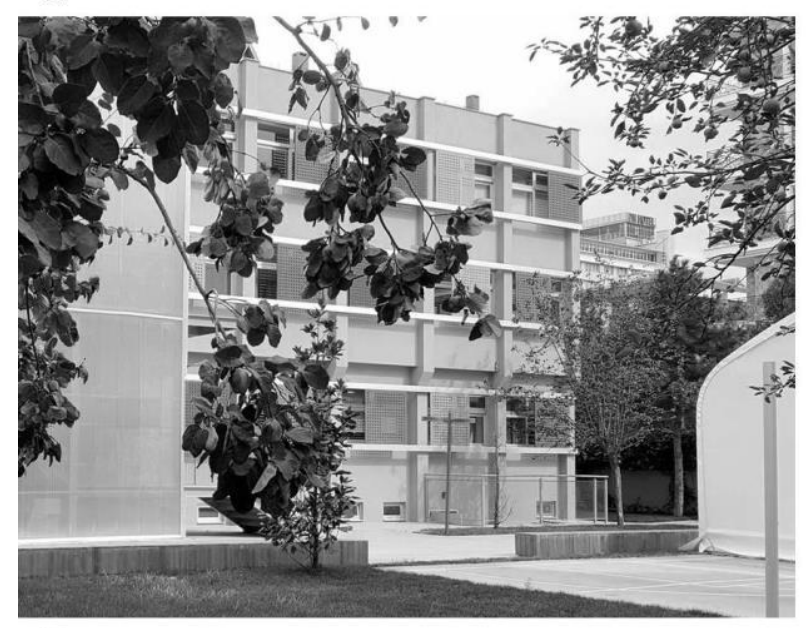

C b

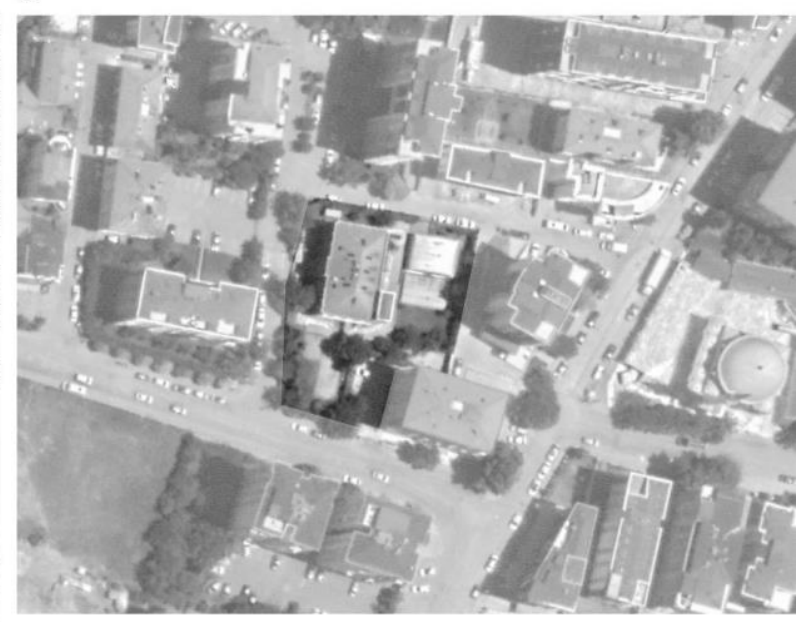

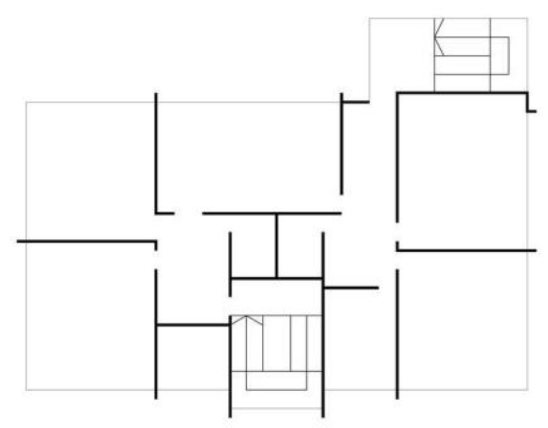

$\begin{array}{lllll}0 & 5 & 10 & 15 & 20\end{array}$

Figure 5. (a) Fide Schools: Idealtepe Campus designed by ddrlp Architecture and Design Services (Arkiv, 2020); (b) Aerial view of Fide Schools: Idealtepe Campus, 2020; (c) Schematic plan drawing of the Main Educational Building of Fide Schools: Idealtepe Campus (Arkiv, 2020).

Beykoz Koç Middle School designed by Cannon Design and DB Architects with the goal of transforming the educational environment. After its construction, the school was donated to the Ministry of Education of Turkey to be used as a public school. Columns in round form provide flexibility in space partitions and in the organization of 21 classrooms at the school.
Non-bearing walls and folding glass dividers are used to divide spaces. Classrooms and offices, which are grouped on the 4 branches of the building are open to common areas obtained by the placement of the units and then to the general circulation areas (Arkitera, 2018) (Figure. 6). 


\section{Journal of}

\section{Design Studio}

a

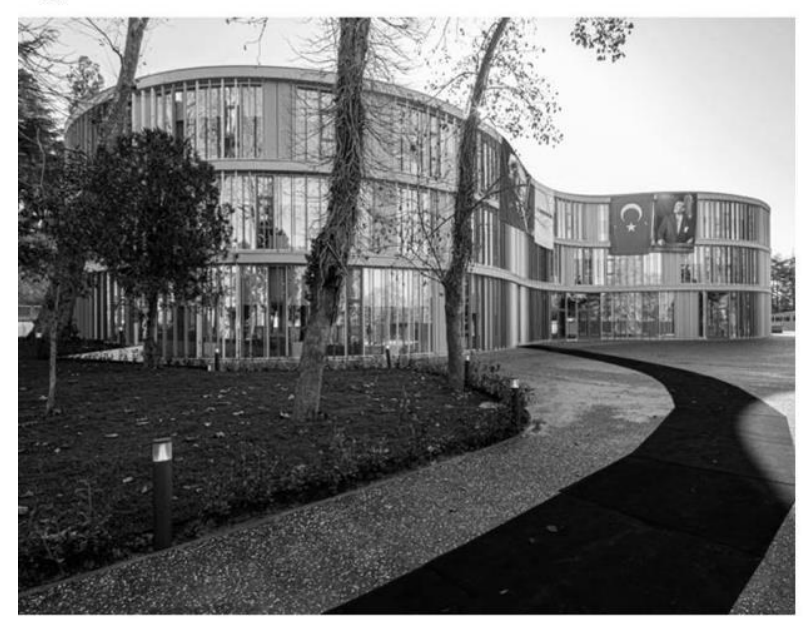

b

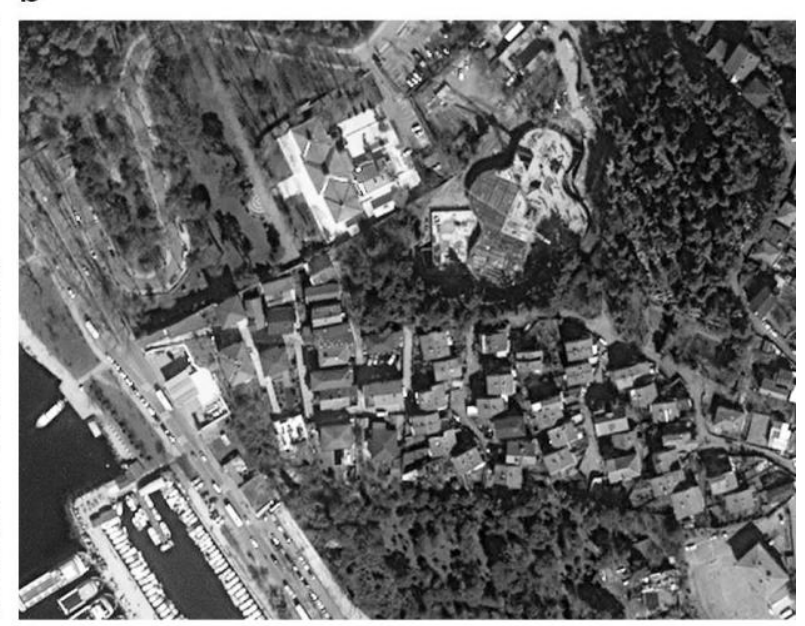

C

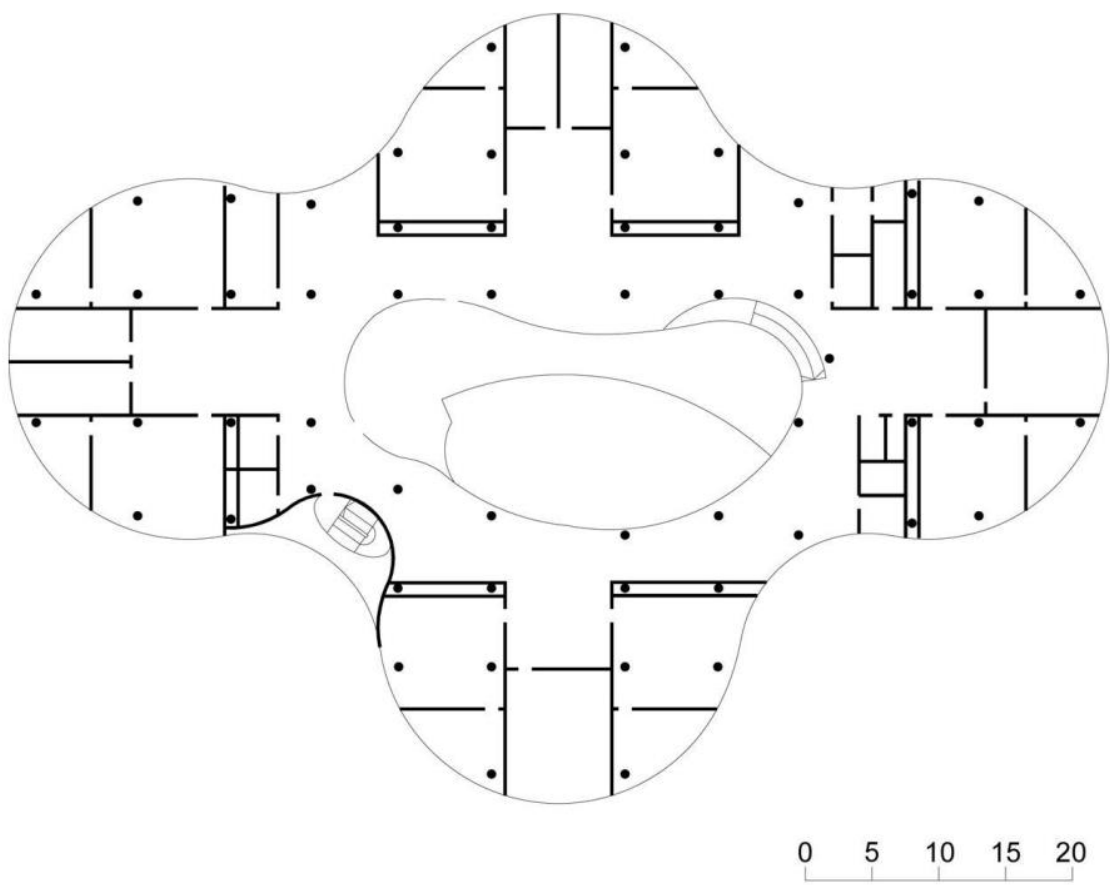

Figure 6. (a) Beykoz Koç Middle School, 2020 (Arkitera, 2018); (b) Aerial view of Beykoz Koç Middle School, 2020; (c) Schematic plan drawing of Beykoz Koç Middle School (Kalender Mimarlık, 2020).

The fifth sample project including 32 classrooms was designed by anonymous architects as a "typical primary school" for the Ministry of National Education of Turkey, Department of Construction, and Real Estate. (Figure 7). The school building consists of a basement floor, ground floor, first floor, second floor, and third floor. The area of the ground floor is $1440 \mathrm{~m}^{2}$. The classrooms, offices, and service areas are located on the upper floors, while the multi-purpose hall and sports area are placed in the basement. Similar to the Akyürek (1973)'s typical project, in the typical project designed in 2020, the classrooms are located on double-sides of the corridor. The contextspecific information such as orientation, climate, environmental conditions, and site plan is not available (Figure 7). 
a

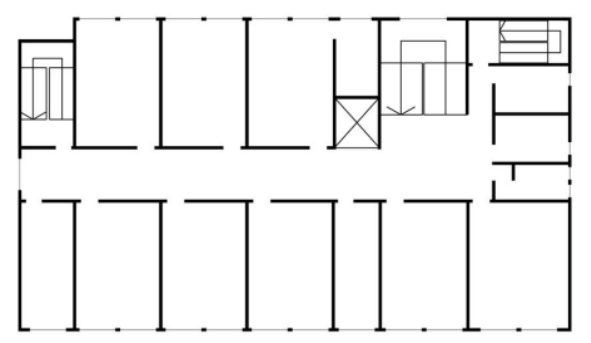

$\square$ Classroom Office U/As Service b

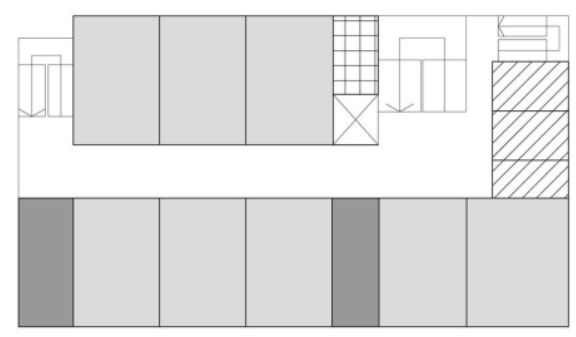

$\begin{array}{lllll}0 & 5 & 10 & 15 & 20\end{array}$

Figure 7. (a) Schematic plan drawing of the "Typical Primary School” (T.C. Milli Eğitim Bakanlı̆̆ İnşaat Emlak Daire Başkanlığl, 2020); (b) Function diagram of "Typical Primary School”.

\subsection{Evaluation}

For over 50 years, Ataköy Primary School has been continuing its educational activities without any major architectural intervention on its building envelope. The plan scheme and its features provide benefit by permitting flexibility within the 2 inner halls and the individual storage areas of each classroom; as such, Ataköy Primary School has the potential to expand the classrooms through the available interior space (voids) to increase the area per student, as needed. A diagram illustrates the possibilities of expanding classrooms and offices without damaging circulation. In this context, Ataköy Primary School is able to operate educational activities under social distancing measures without changing the number of students, number of teachers, and/or number of classrooms; this is a positive outcome of the plan layout (Figure 8a, b).
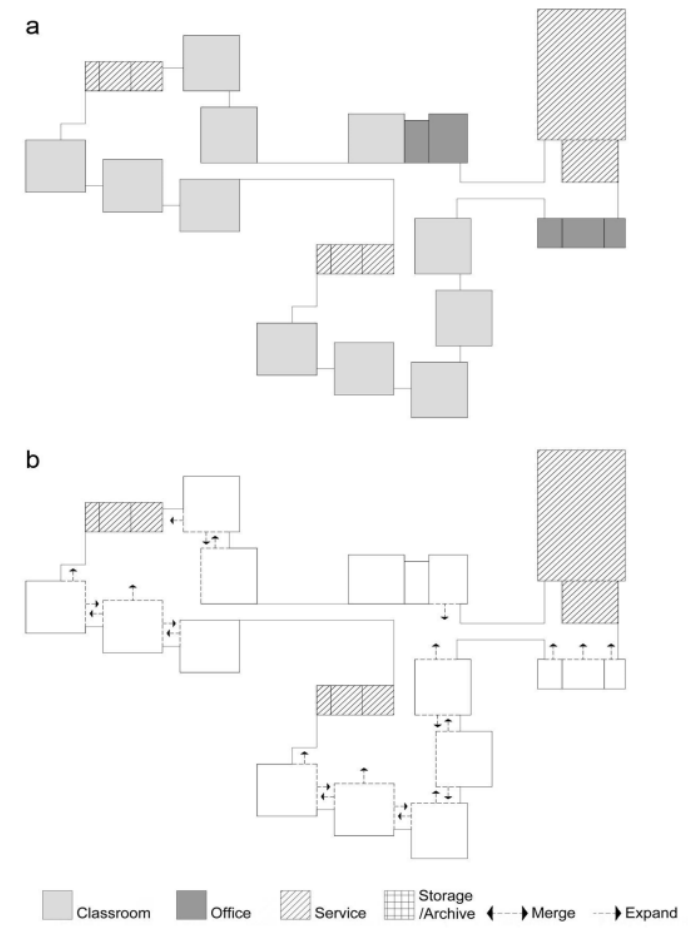

Figure 8. (a) Function diagram of Ataköy Primary School; (b) Flexibility diagram of Ataköy Primary School. 


\section{Journal of}

\section{Design Studio}

In Beykoz Koç Middle School, the voids designed with the purpose of common use, the storage areas in the classrooms and circulation areas are significantly wider than the provided guidelines and frameworks, which ensures the possibility of expansion through the interior of the building. The diagram below, (Figure 9a), shows the potential of merging storage areas to classroom space when necessary. Figure $9 \mathrm{~b}$ also shows the partition walls and glass dividers of classrooms can be shifted through the circulation area to accommodate social distancing measures without eliminating any classrooms.
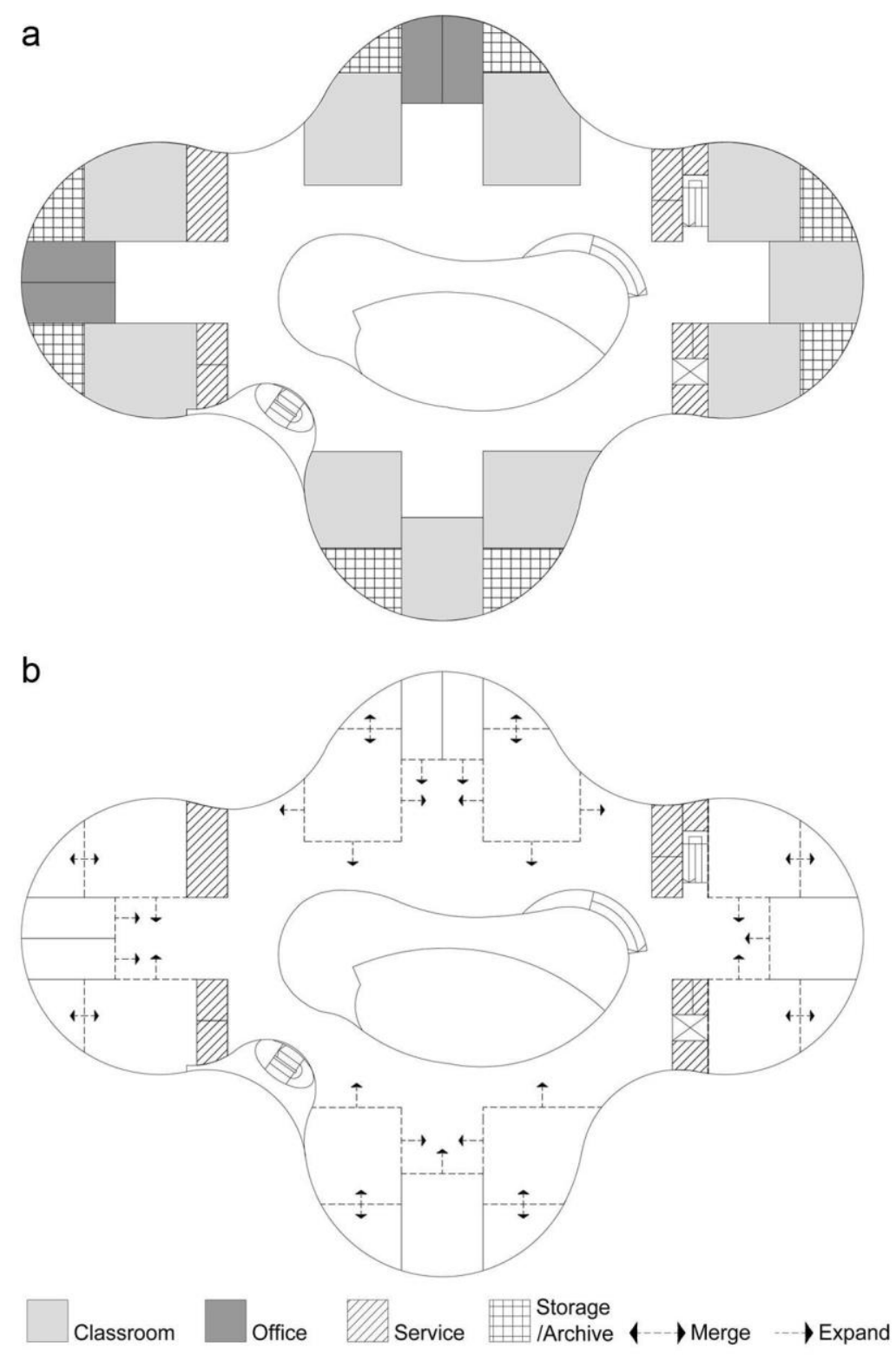

Figure 9. (a) Function Diagram of Beykoz Koç Middle School; (b) Flexibility diagram of Beykoz Koç Middle School. 


\section{Journal of}

\section{Design Studio}

v:2 n:2 December 2020

\begin{tabular}{l|l|l|l}
\hline Table 2. Comparison of selected school buildings/projects in terms of flexibility. \\
$\begin{array}{l}\text { School } \\
\text { Buildings }\end{array}$ & $\begin{array}{l}\text { Plan } \\
\text { Typology }\end{array}$ & $\begin{array}{l}\text { Potential to Expand } \\
\text { through Interior }\end{array}$ & $\begin{array}{l}\text { Potential to Expand } \\
\text { through Exterior }\end{array}$ \\
\hline Ataköy Primary School & Unique & + & + \\
\hline Kocasinan MPAHS & Typical & - & + (limited) \\
\hline Fide Schools: İdealtepe Campus & Unique & - & + \\
\hline Beykoz Koç Middle School & Unique & + & + (limited) \\
\hline Typical Primary School & Typical & - & (no specific site)
\end{tabular}

Among the examined school plans, Ataköy Primary School, with its "open-plan layout" demonstrates a higher ability to adapt. The plan typologies and circulation areas in schools where the minimum dimensions are employed such as the typical middle school project
(Kocasinan MPAHS) and Fide Schools: İdealtepe Campus Educational Buildings, and "Typical Primary School" project represent the absence of any potential for expanding classrooms through the interior (Table 2). a

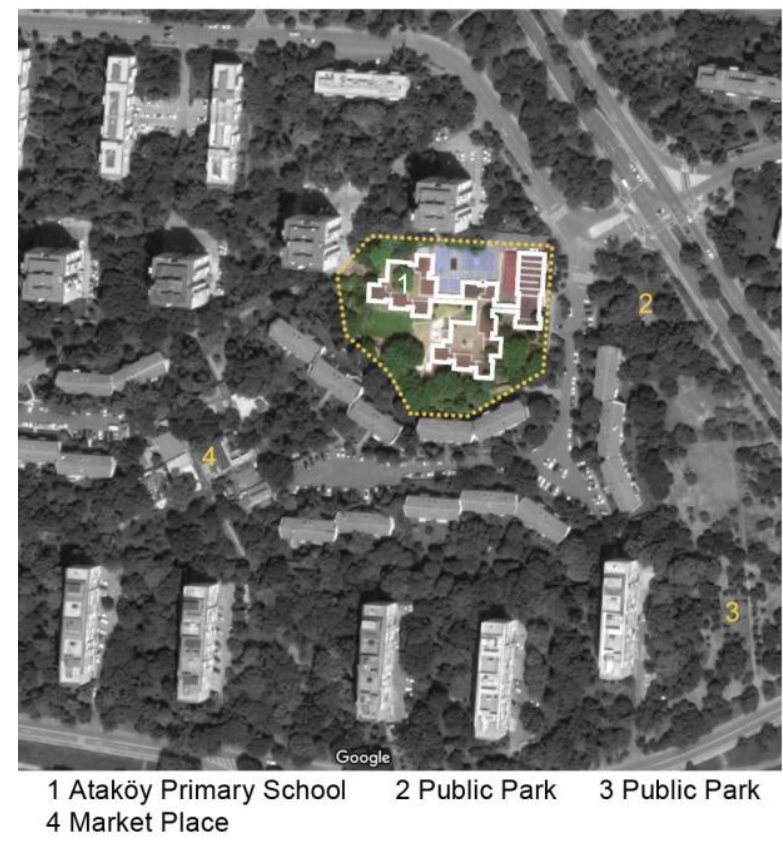

b

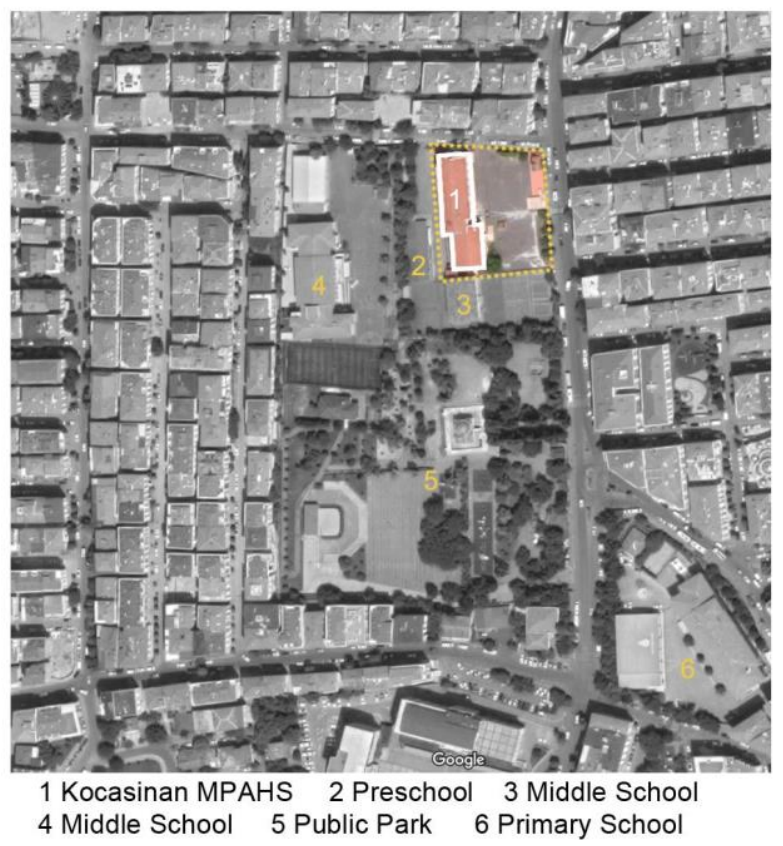

Figure 10. (a) Aerial view of Ataköy Primary School and its surroundings, 2020; (b) Aerial view of Kocasinan MPAHS and its surroundings, 2020.

Regarding the ability to expand through the exterior area, Ataköy Primary School involves more ambiguous boundaries. Ataköy Primary School is surrounded by low-density high-rise residential buildings and green area that allows pedestrian access to the school building (Figure 10a). On the other hand, Kocasinan MPAHS consists of clearly defined boundary elements. 


\section{Journal of \\ Design Studio \\ $\mathrm{v}: 2 \mathrm{n}: 2$ December 2020}

While four individual school buildings (Figure 10b) are located close to each other, there is no direct access to neither public park nor other school building's courtyards. In such a dense urban environment (Figure 10b), the total open space that belongs to the school is smaller than the total area of the building. Therefore, the potential to expand to the exterior remains limited. Similar to Kocasinan MPAHS, Fide Schools: İdealtepe Campus Educational Building is located in a relatively dense environment. However, Fide Schools: İdealtepe Campus Educational Building has the potential to expand to the exterior, especially to the

\section{a}

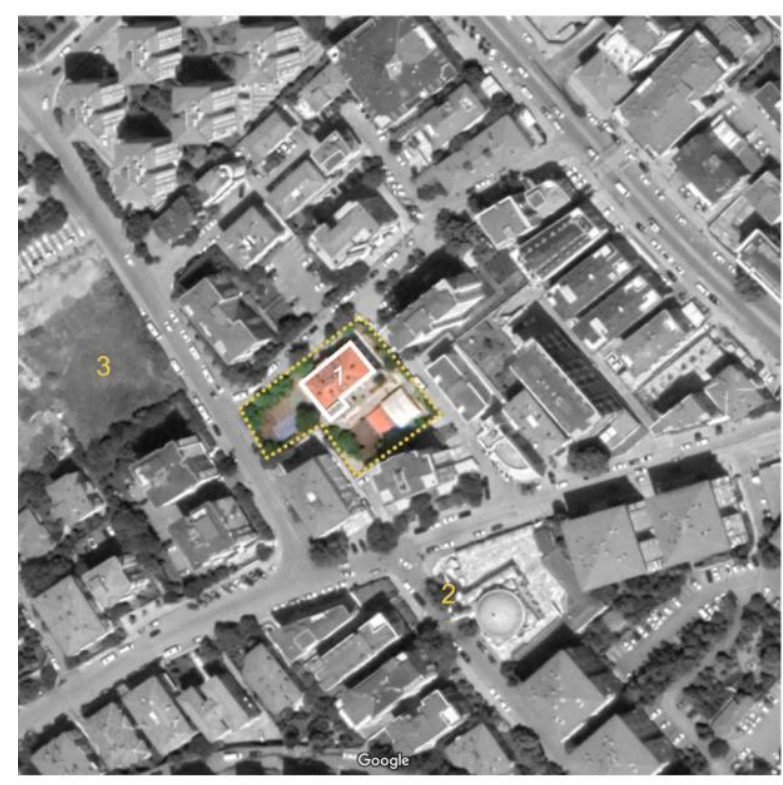

1 Fide Schools: İdealtepe Campus 2 Mosque 3 Empty Field courtyard, considering the size of the reserved open space is equal to the size of the building itself (Figure 11a). Beykoz Koç Middle School has a unique plan typology, however, the defined outdoor space that can be used as a courtyard is limited, as it is surrounded by a public park, playground, and cemeteries (Figure 11b). Since the context-free "Typical Primary School" has not been constructed and has no site plan available, it is not possible to evaluate the potentials of expanding through exterior space and relationship with its surrounding.

\section{b}

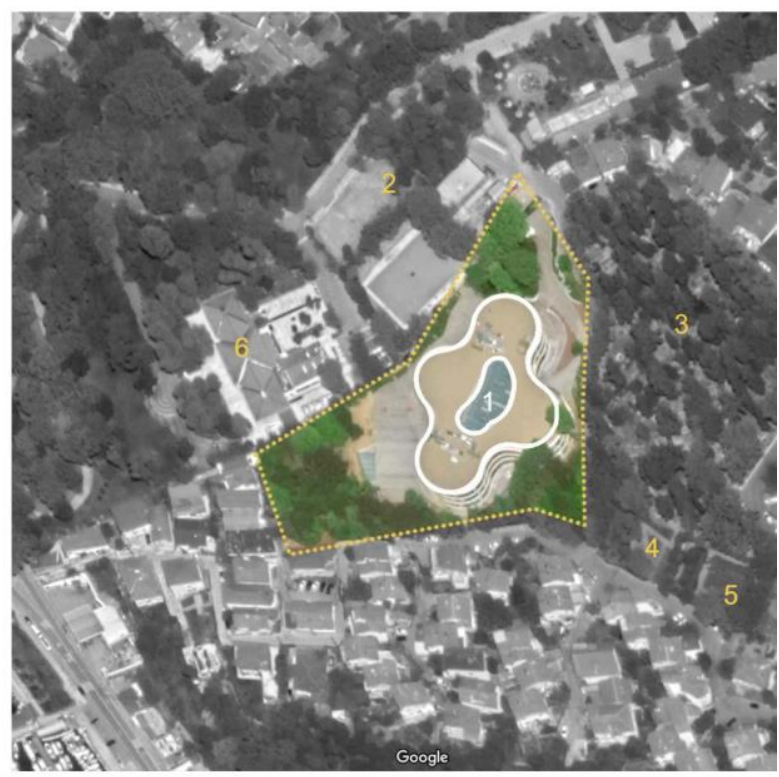

1 Beykoz Koç Middle School 2 Cemetery 3 Cemetery

4 Public Park 5 Playground 5 Leisure Center

Figure 11. (a) Aerial view of Fide Schools: Idealtepe Campus and its surroundings, 2020; (b) Aerial view of Beykoz Koç Middle School and its surroundings, 2020.

\section{Concluding Remarks}

This study introduces three levels of adaptation for existing educational buildings to adapt to new needs derived from the post-pandemic process as: (i) Building envelope-outdoor space relationship, (ii) Plan layout-function relationship, and (iii) Furniture relocation. Among the introduced three levels, plan layoutfunction relationship level is examined in detail in the context of flexibility through the five selected school plans from the periods between the 1960s to 2020s. Four of the selected samples with varying plan types are located in İstanbul, while the fifth plan belongs to a typical project without a location. Due to high urban density, interventions to building envelopes in İstanbul are limited. Therefore, the building envelope level is excluded within this study. This study attempts to develop a systematic approach to frame potential problems regarding the adaptation of existing educational buildings to 


\section{Journal of \\ Design Studio}

v:2 n:2 December 2020

the post-pandemic process, rather than providing solutions to the identified questions.

A major problem in the design of existing educational buildings in Turkey stems from adhering very closely to the minimum dimension standards described in the building guidelines/codes, rather than providing void spaces. The decision of creating maximum closed areas grants short term advantages, however, given the long-term scenarios, such designs have disadvantages when it comes to the adaptation of educational spaces to any changes. In that sense, most educational buildings with a typical project design cannot meet the expected social distancing measures. On the other hand, voids in the interior spaces and potential open spaces as gardens/courtyards support the adaptability of the educational buildings.

Creating designs where corridors are given more flexibility allows the spaces to be changed as needed, which provides an advantage, in light of Covid-19. Assuming the interior walls as "changeable" (i.e. non-structural elements such as moveable-panels, sliding cabinets, etc.) and "fixed" (i.e. structural elements) in earlier design phases have been providing flexibility prior to Covid-19, and still provides an advantage for the post-pandemic process. Therefore, Karabey (2004)'s “flexibility of interior spaces" principle remains valid for the adaptation of educational buildings to postpandemic re-use.

In the post-pandemic setting, uses of any kind of circulation area, especially elevators become problematic. Having single entrances to educational buildings when considering health and safety (i.e. disinfecting stations, one-way traffic, etc.) creates a barrier of accessibility for students and staff to open areas (i.e. courtyards). Mechanical heating and cooling systems remain as an unsolved problem and this problem has the potential to grow, with seasonal changes (i.e. winter, time spent indoors, heating, etc.). Based on these shortcomings, it is recommended that regulations and guidelines prepared for educational building design be reevaluated and updated as necessary.
Long-term adaptation of educational buildings is excluded from the scope of this study. Additionally, the changes in the speed of Covid19 spread may trigger new and emerging needs that may not have been specified in this study. Adaptation of educational buildings to new needs is primarily related to the number of students. Therefore, similar plan layouts may lead to different results. Turkey's Nationwide Standardized Examination to Enter Secondary School (LGS 2020) was held on June 20, 2020. The standardized examination process was carried on by solely increasing the number of schools (by 5 times) to meet social distancing measures. However, these measures will not be feasible for the upcoming school year due to limitations in resources (infrastructural; building stock). Adaptation of educational buildings to the emerging needs of postpandemic scenarios, like Covid-19, can also be considered as an opportunity to revisit past, present, and future approaches and methods of education.

\section{Acknowledgement:}

The current research activities of the corresponding author are supported by The Scientific and Technological Research Council of Turkey (grant no: 1059B191900560).

\section{References:}

Abbasi, N. (2016). Adolescent identity formation and the school environment, In Kenn Fisher (Ed.), The Translational Design of Schools (pp. 81-103). Rotterdam: Sense Publishers.

Akyürek, O. (1973). Bir Orta Okul Binası. Arkitekt, 350, 70.

Arkitera (2018, December 18). Retrieved July 30, 2020, from https://www.arkitera.com/haber/the-thirdteacher-kitabindan-esinlenen-model-okulbeykoz-koc-ortaokulu/ 


\section{Journal of}

\section{Design Studio}

v:2 n:2 December 2020

Arkiv (2020). Retrieved July 30, 2020, from http://www.arkiv.com.tr/proje/fideokullari/6495

da Graça, V. A. C., Kowaltowski, D. C. C. K., \& Petreche, J. R. D. (2007). An evaluation method for school building design at the preliminary phase with optimisation of aspects of environmental comfort for the school system of the State São Paulo in Brazil. Building and Environment, 42(2), 984-999.

Dovey, K., \& Fisher, K. (2014). Designing for adaptation: The school as socio-spatial assemblage. The Journal of Architecture, 19(1), 43-63.

Dudek, M. (2007). A design manual schools and kindergartens. Berlin: Birkhäuser Verlag AG.

Fide Okulları (2020). Retrieved July 30, 2020, from https://www.fideokullari.k12.tr/okulumuz/ideal tepe-kampusu

Giray, M. (1967). Ataköy İkinci Mahalle İlkokulu. Arkitekt, 326, 58-61.

İstanbul Bahçelievler Kocasinan Çok Programlı Anadolu Lisesi (2020). http://kocasinancpal.meb.k12.tr/meb_iys_dosy alar/34/28/973089/fotograf_galerisi_476394.ht ml\#gallery-

\%20(Eri\%C5\%9Fim\%20Tarihi:\%208\%20Hazi $\operatorname{ran} \% 202020$ )

Karabey, H. (2004). Eğitim Yapıları Geleceğin Okullarını Planlamak ve Tasarlamak Çağdaş Yaklaşımlar, İlkeler. İstanbul: Literatür Yayınları.

Kalender Mimarlık (2020). Retrieved July 30, 2020, from http://www.kalendermimarlik.com/2018/03/14 /beykoz-ortaokul-projesi/

Kızıltan, A. (1967). Birleşik Amerikada Eğitim ve İlkokul Planlaması Yöntemler ve Ë̆ilimler. İstanbul: İsmail Akgün Matbaası.
Köse, Ç., \& Barkul, Ö. (2012). İlköğretim Yapılarında Tip Proje Uygulama Sorunları Üzerine Bir İnceleme. Megaron, 7(2), 94-102.

Online Etymology Dictionary (2020). Retrieved July 30, 2020, from https://www.etymonline.com/word/pandemic Pereira, P. R. P., Kowaltowski, D. C. C. K., \& Deliberador, M. S. (2018). Analysis support for the design process of school buildings. Ambiente Construído, 18(3), 375-390.

Tapkı, S., \& Canbay Türkyılmaz, Ç. (2018). İlköğretim Yapılarında Ergonomi Kavramının İncelenmesi: TİP Proje İlkokulu ile Tasarım Projesi İlkokulunun Karşılaştırılması. Mühendislik Bilimleri ve Tasartm Dergisi, 6(ÖS: Ergonomi2017), 220-233.

T.C. Milli Eğitim Bakanlığı (2019). Milli Eğitim İstatistikleri, Örgün Eğitim 2018/'19. Retrieved from https://sgb.meb.gov.tr/meb_iys_dosyalar/2019 _09/30102730_meb_istatistikleri_orgun_egiti m_2018_2019.pdf

T.C. Milli Eğitim Bakanlığı (2020, March 13). Özel Kurslar da 16-30 Mart'ta Tatil. Retrieved from http://www.meb.gov.tr/ozel-kurslar-da16-30-martta-tatil/haber/20508/tr

T.C. Milli Eğitim Bakanlığı (2020, March 17). Uzaktan Eğitimde İlk Dersi Bakan Ziya Selçuk Verecek. Retrieved from http://www.meb.gov.tr/uzaktan-egitimde-ilkdersi-bakan-ziya-selcukverecek/haber/20530/tr1

T.C. Milli Eğitim Bakanlığı İnşaat Emlak Daire Başkanlığı (2020, August 26). https://bulut.meb.gov.tr/app/tr-

TR/App/Download/MEBBulut/bdabfd9e0e06-40b7-a8f8-9a877a0d19e3

TRT Haber (2018, January 14). Retrieved July 30, 2020, from https://www.trthaber.com/haber/gundem/ikiliegitim-2019da-tarihe-karisiyor-

346471.html\%20(Eri\%C5\%9Fim\%20Tarihi:\% 208\%20Haziran\%202020) 


\section{Journal of \\ Design Studio \\ v:2 n:2 December 2020}

Woodman, K. (2016). Re-placing flexibility: Flexibility in learning spaces and learning, In Kenn Fisher (Ed.), The Translational Design of Schools (pp. 51-79). Rotterdam: Sense Publishers.

Worldometer (2020). Retrieved July 30, 2020, from

https://www.worldometers.info/coronavirus/?u tm_campaign=homeAdvegas $1 \% \% 22$

World Health Organization (2010, February 24). What is a pandemic? Retrieved from https://www.who.int/csr/disease/swineflu/frequ ently_asked_questions/pandemic/en/

World Health Organization (2020, March 11). WHO Director-General's opening remarks at the media briefing on COVID-19. Retrieved from

https://www.who.int/dg/speeches/detail/who- director-general-s-opening-remarks-at-themedia-briefing-on-covid-19---11-march-2020

Yürekli, F. (1983). Mimari Tasarımda Belirsizlik Esneklik/Uyarlı Ihtiyacının Kaynakları ve Çözümü Üzerine Bir Araştırma. (Thesis of Associate Professorship), İstanbul: İTÜ Mimarlık Fakültesi Baskı Atölyesi. 